\title{
Supplementary material for "The control of climate sensitivity on variability and change of summer runoff from two glacierised Himalayan catchments"
}

Sourav Laha ${ }^{1}$, Argha Banerjee ${ }^{1}$, Ajit Singh ${ }^{2}$, Parmanand Sharma ${ }^{2}$, and Meloth Thamban ${ }^{2}$

${ }^{1}$ Earth and Climate Science, Indian Institute of Science Education and Research (IISER) Pune, Pune-411008, India

${ }^{2}$ National Centre for Polar and Ocean Research (NCPOR), Ministry of Earth Sciences, Vasco-da-Gama, Goa-403804, India

Correspondence: Argha Banerjee (argha@iiserpune.ac.in) 
Table S1. Details of the hydrometeorological observations used in this study. All hydro-meteorological data of upper Dudhkoshi catchment (Chevallier et al., 2017) are accessible from http://www.papredata.org/.

\begin{tabular}{|c|c|c|c|}
\hline Parameters (station name) & Sensor & $\begin{array}{l}\text { Accuracy } \\
\text { (Range) }\end{array}$ & Data availability \\
\hline \multicolumn{4}{|c|}{ Chandra catchment (Pratap et al., 2019; Singh et al., 2020) } \\
\hline Runoff (Tandi) & YSI radar & $\pm 2 \mathrm{~mm}$ & $\begin{array}{l}\text { 26Th June, } 2016 \text { to 30th Oct, } \\
2018 \text { (with gaps) }\end{array}$ \\
\hline Precipitation (Himansh) & $\begin{array}{l}\text { OTT Pluvio precipita- } \\
\text { tion bucket }\end{array}$ & $\pm 0.05 \mathrm{~mm}$ & $\begin{array}{l}\text { 18th Oct, } 2015 \text { to 5th Oct, } 2018 \\
\text { (with gaps) }\end{array}$ \\
\hline $2 \mathrm{~m}$ air temperature (Himansh) & Campbell HC2S3 & $\begin{array}{l} \pm 0.1^{\circ} \mathrm{C}(-50 \text { to }+60 \\
\left.{ }^{\circ} \mathrm{C}\right)\end{array}$ & $\begin{array}{l}\text { 18th Oct, } 2015 \text { to 5th Oct, } 2018 \\
\text { (with gaps) }\end{array}$ \\
\hline $\begin{array}{l}\text { Incoming shortwave radiation (Hi- } \\
\text { mansh) }\end{array}$ & $\begin{array}{l}\text { Kipp and Zonen } \\
\text { four component net } \\
\text { radiometer }\end{array}$ & $\begin{array}{l}<5 \% \text {-day total }(305- \\
2800 \mathrm{~nm}, \quad 0-2000 \\
\left.\mathrm{Wm}^{-2}\right)\end{array}$ & $\begin{array}{l}\text { 18th Oct, } 2015 \text { to 5th Oct, } 2018 \\
\text { (with gaps) }\end{array}$ \\
\hline \multicolumn{4}{|c|}{ Upper Dudhkoshi catchment (Chevallier et al., 2017; Sherpa et al., 2017) } \\
\hline Runoff (Phadking) & $\begin{array}{l}\text { Campbell sensor (de- } \\
\text { tails not available) }\end{array}$ & & $\begin{array}{l}\text { 7th April } 2010 \text { to 16th April } \\
2017\end{array}$ \\
\hline Precipitation (Phadking) & $\begin{array}{l}\text { Campbell sensor (de- } \\
\text { tails not available) }\end{array}$ & & $\begin{array}{l}\text { 7th April } 2010 \text { to 23th April } \\
2017 \text { (with gaps) }\end{array}$ \\
\hline $2 \mathrm{~m}$ air temperature (Phadking) & $\begin{array}{l}\text { Campbell sensor (de- } \\
\text { tails not available) }\end{array}$ & & $\begin{array}{l}\text { 7th April } 2010 \text { to 23th April } \\
2017 \text { (with gaps) }\end{array}$ \\
\hline $2 \mathrm{~m}$ air temperature (Changri Nup) & Vaisala HMP45C & $\pm 0.2^{\circ} \mathrm{C}$ & $\begin{array}{l}\text { 1st Nov, } 2010 \text { to 30th Nov, } \\
2014\end{array}$ \\
\hline $\begin{array}{l}\text { Incoming shortwave radiation (Changri } \\
\text { Nup) }\end{array}$ & Kipp and Zonen CNR4 & $\begin{array}{l} \pm 3 \% \text {-day total }(0.305- \\
2.8 \mu \mathrm{m})\end{array}$ & $\begin{array}{l}\text { 1st Nov, } 2010 \text { to 30th Nov, } \\
2014\end{array}$ \\
\hline
\end{tabular}



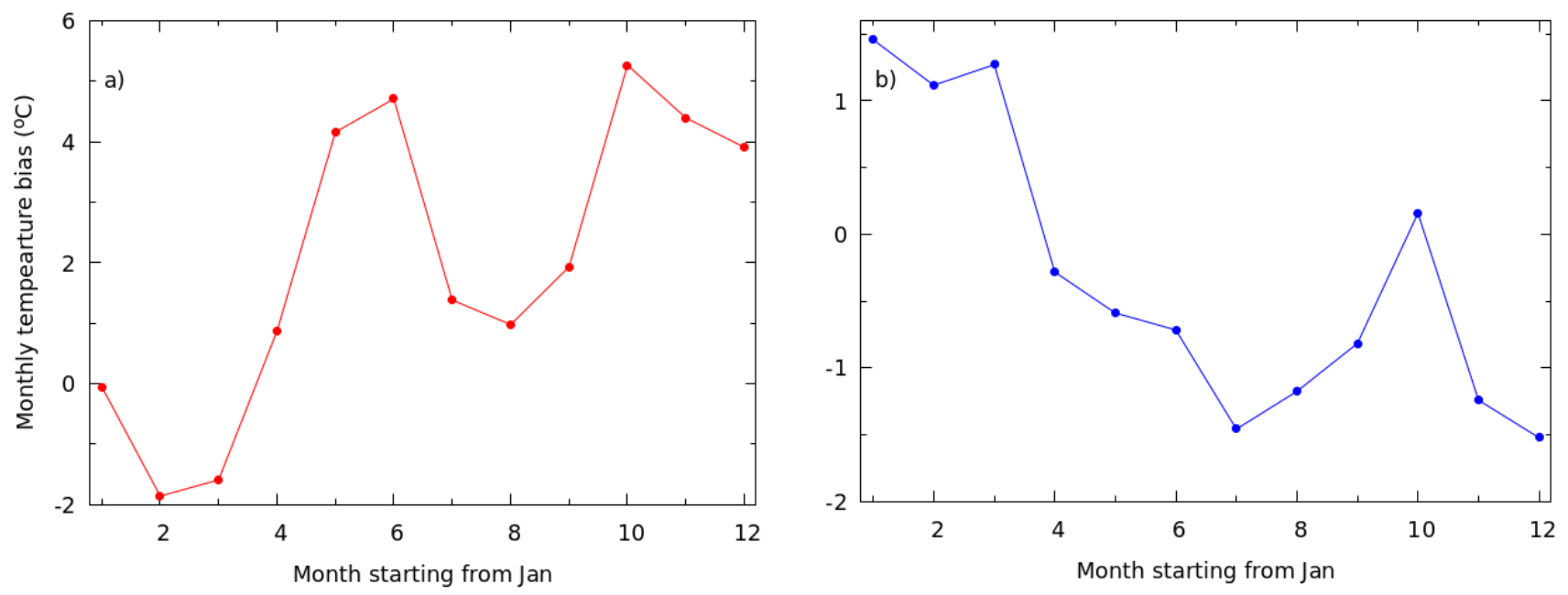

Figure S1. Mean monthly bias in ERA5 $2 \mathrm{~m}$ air temperature for (a) Chandra, and (b) upper Dudhkoshi catchments with respect to the corresponding stations (Himansh and Phadking, respectively). 


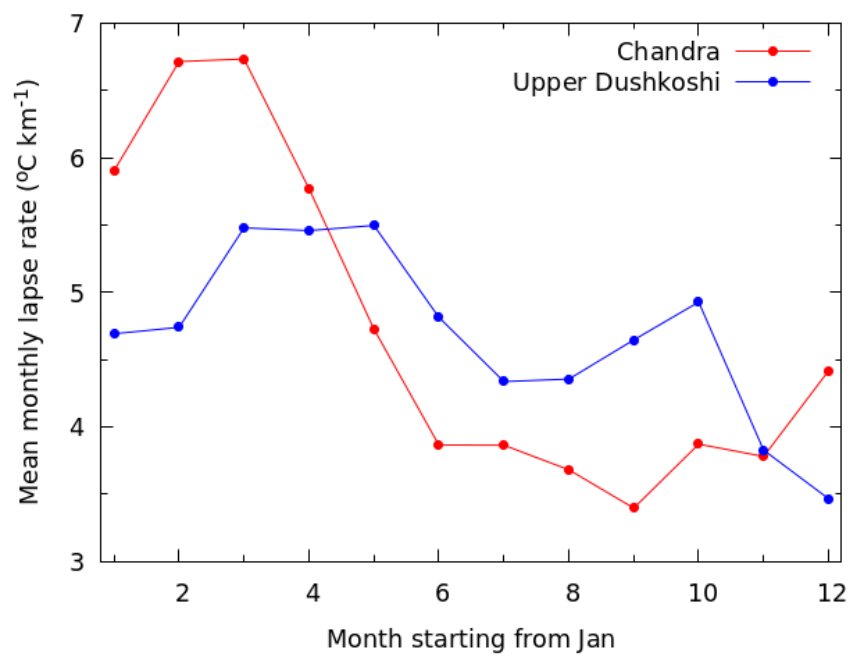

Figure S2. The mean monthly temperature lapse rates for Chandra (red symbols + line) and upper Dudhkoshi (blue symbols + line) catchments. In Chandra catchment the lapse rate was computed at the gridbox containing Himansh station from the ERA5 data (1980-2018) using temperature from four near-neighbour gridboxes. The mean annual lapse rate in Chandra catchment was $4.7 \pm 1.2^{\circ} \mathrm{C} \mathrm{km}^{-1}$, consistent with the available mean annual lapse rate estimates of 4.4-6.4 ${ }^{\circ} \mathrm{C} \mathrm{km}^{-1}$ (Azam et al., 2014; Pratap et al., 2019). In upper Dudhkoshi catchment, data from two stations Phadking and Changri Nup over the period 2013-2016 were used compute the lapse rate. The mean annual lapse rate was $4.6 \pm 0.6{ }^{\circ} \mathrm{C} \mathrm{km}^{-1}$ which was consistent with the previously reported value of $4.6{ }^{\circ} \mathrm{C} \mathrm{km}^{-1}$ (Pokhrel et al., 2014) from the same catchment. In this catchment, the lapse rate derived from ERA5 was significantly larger than the observed value. 

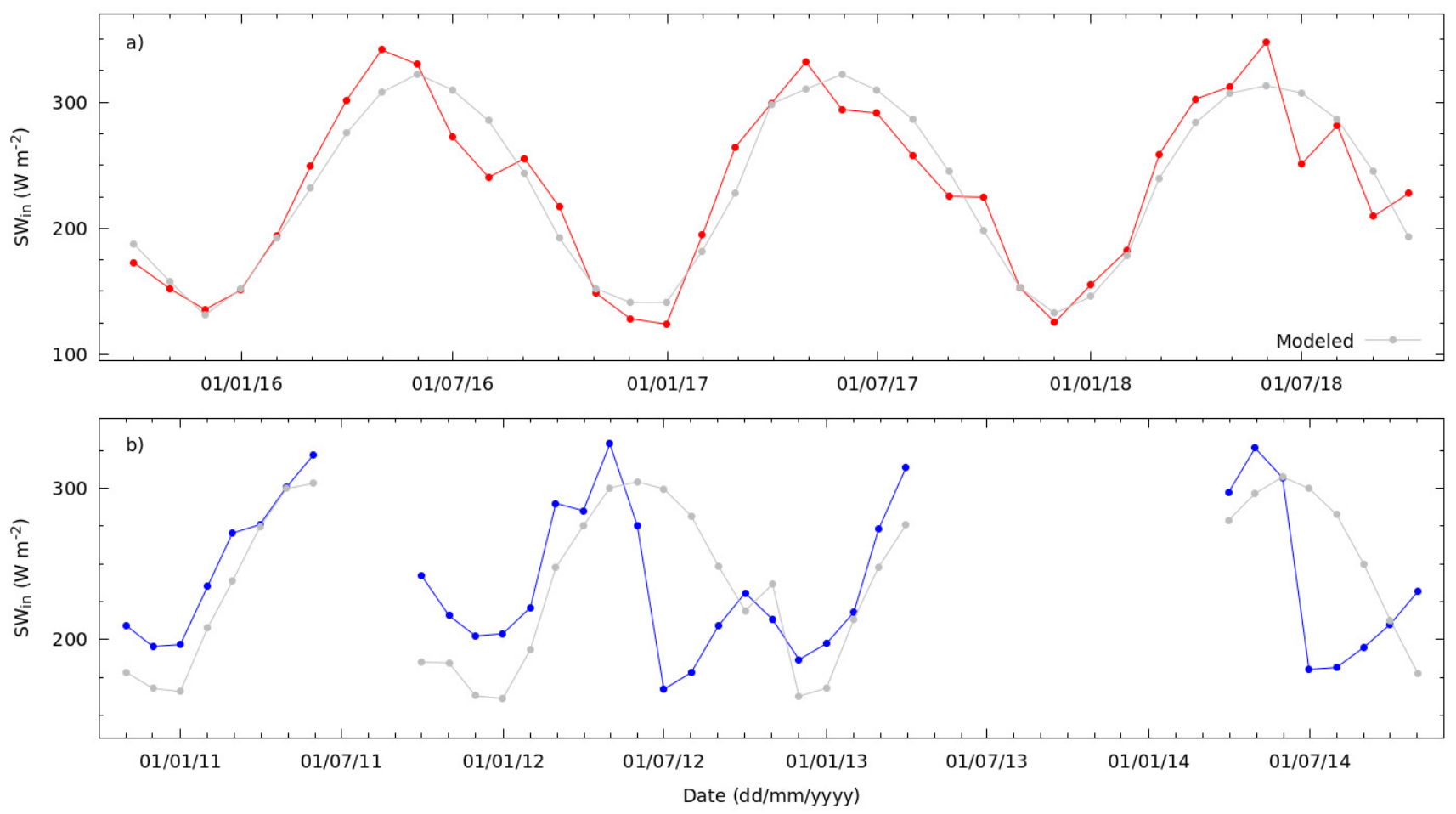

Figure S3. The incoming shortwave radiation $\left(S W_{i n}\right)$ estimated by VIC model was scaled so that it matched that observed at Himansh (Chandra catchment) and Changri Nup (upper Dudhkoshi catchment). In this plot, monthly modelled $S W_{i n}$ (gray lines + symbols) were shown for (a) Chandra, and (b) upper Dudhkoshi catchment, respectively. The corresponding monthly observed $S W_{i n}$ for Chandra (upper Dudhkoshi) catchment was shown by red lines + symbols (blue lines + symbols). In Chandra (upper Dudhkoshi) catchment the correction factor used was 2.1 (0.71). 
Table S2. The values of the model parameters used in simulations.

\begin{tabular}{lcc}
\hline Parameter & Range & Value used here \\
\hline \hline & VIC model parameters (https://vic.readthedocs.io/en/master/) \\
\hline$D s$ & $0.1-0.5$ & 0.35 \\
$D s_{\text {max }}\left(\mathrm{mm} \mathrm{day}^{-1}\right)$ & $10-20$ & 15 \\
$W s$ & $0.4-1.0$ & 0.7 \\
$b_{\text {inf }}$ & $0.001-0.100$ & 0.050 \\
$T_{\text {th }}\left({ }^{\circ} \mathrm{C}\right)$ & $-1.0-1.0$ & 0.0 \\
\hline \multicolumn{3}{c}{ Glacier runoff (Hannah and Gurnell, 2001) } \\
\hline$K_{\text {fast }}(\mathrm{hr})$ & $1-24$ & 12 \\
$K_{\text {slow }}(\mathrm{hr})$ & $500-2000$ & 1200 \\
\hline & Routing model (Lohmann et al., 1998$)$ \\
\hline$U H_{\text {max }}^{F}(\mathrm{hr})$ & $0.5-4.0$ & 2 \\
$U H_{\text {pow }}^{F}(\mathrm{hr})$ & $2-6$ & 4 \\
$B f(\mathrm{hr})$ & $1000-3000$ & 2000 \\
$K s(\mathrm{hr})$ & $100-1000$ & 550 \\
\hline
\end{tabular}



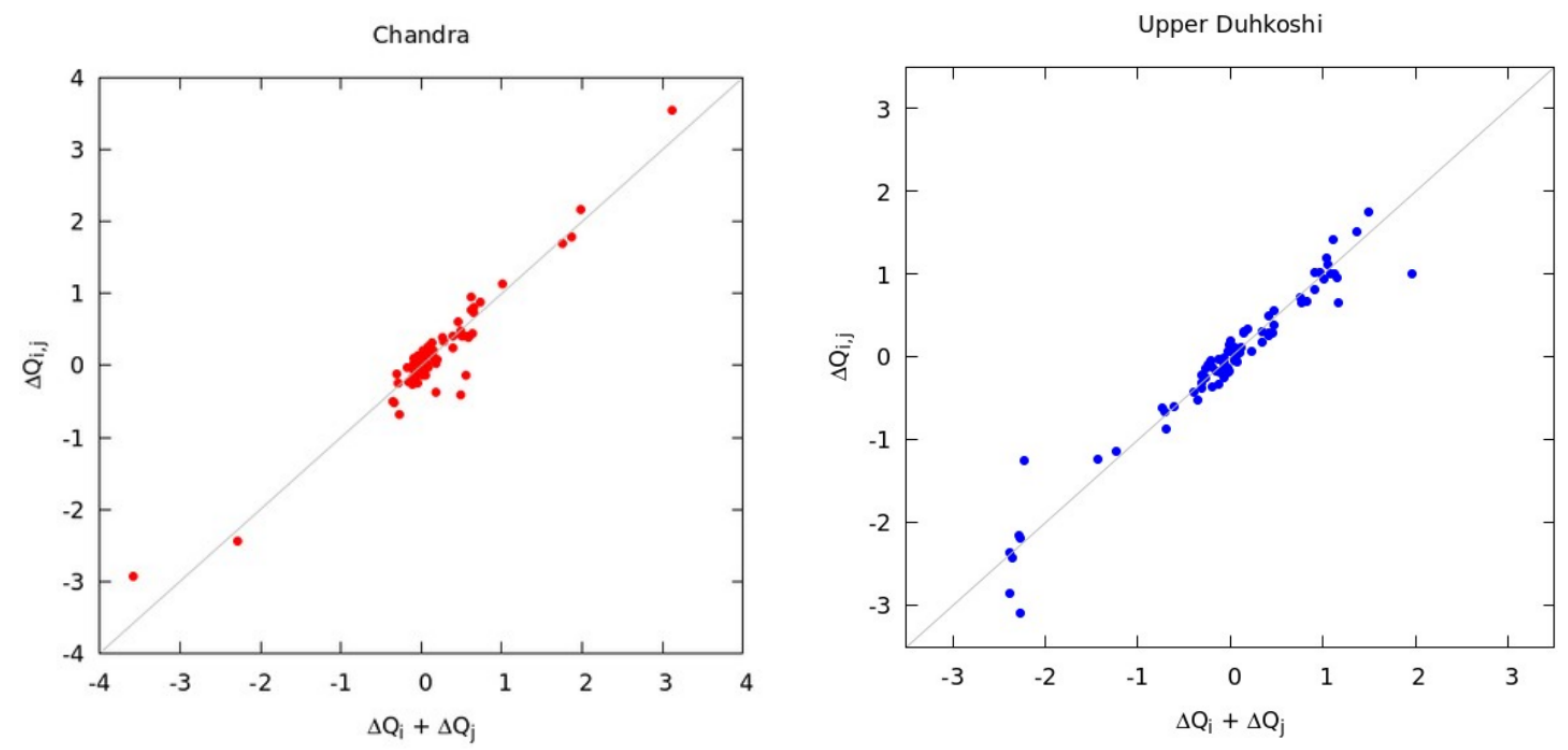

Figure S4. Percentage changes in runoff $\left(\Delta Q_{i, j}\right)$ in 80 model runs, where two randomly chosen parameters out of the 11 VIC model parameters were perturbed simultaneously, are plotted against the sum of the runoff changes $\left(\Delta Q_{i}+\Delta Q_{j}\right)$ from two corresponding experiments where only one of the two parameters were perturbed. 

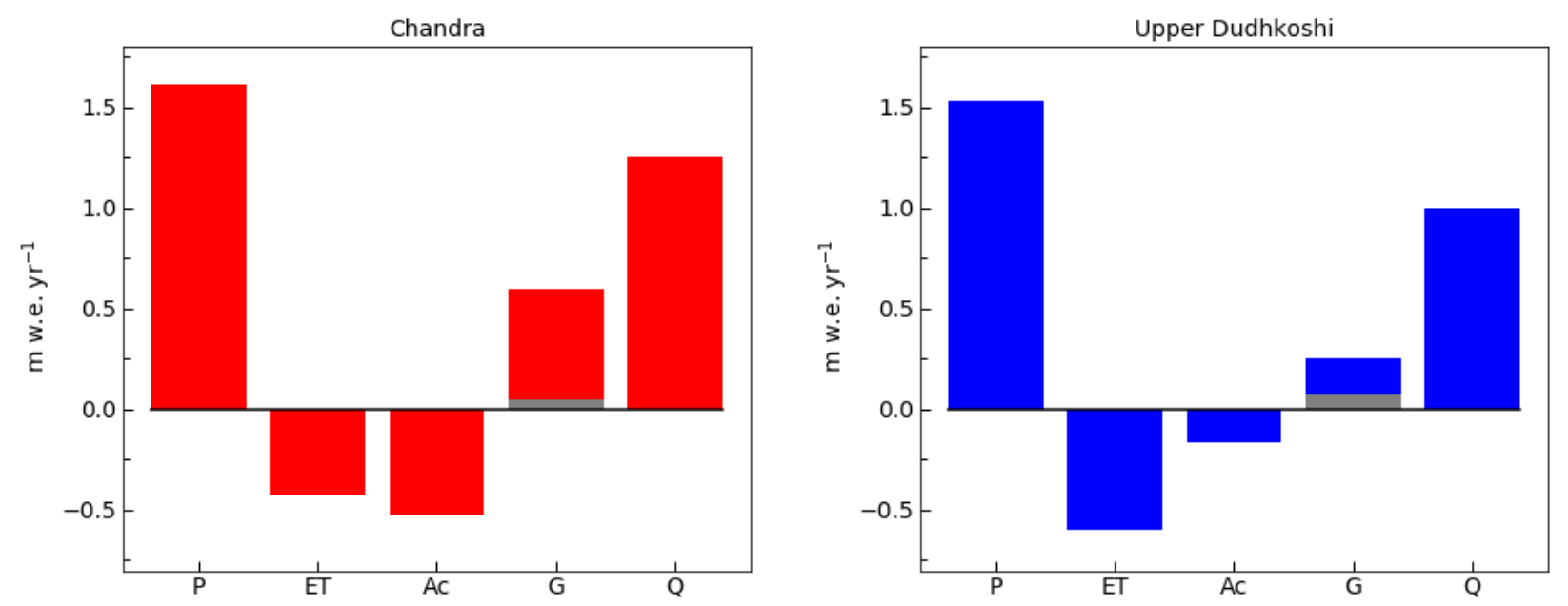

Figure S5. The components of annual hydrological balance equation $P-E T-A c+G=Q$ are shown for the two catchments. All the components are normalised by the total catchment area. $P, E T, A c, G$, and $Q$ are the annual precipitation, evapotranspiration, glacier accumulation, the runoff from glacerised area, specific runoff from whole catchments, respectively. The imbalance contributions of the glaciers are also shown with grey bars. 
Table S3. A comparison of modelled glacier mass balance with the available regional geodetic mass balance for both the catchments. For the modelled mass balance values marked with ${ }^{*}$, the modelled mean were computed starting from the year 1980.

\begin{tabular}{|c|c|c|}
\hline Period & $\begin{array}{l}\text { Mean modelled mass balance } \\
\left(\mathrm{m} \text { w.e } \mathrm{yr}^{-1}\right)\end{array}$ & $\begin{array}{l}\text { Geodetic mass balance (reference) } \\
\left(\mathrm{m} \mathrm{w.e} \mathrm{yr}^{-1}\right)\end{array}$ \\
\hline \multicolumn{3}{|c|}{ Chandra catchment } \\
\hline 1980-2018 & $-0.18 \pm 0.10$ & \\
\hline 1980-1992 & $0.29 \pm 0.18$ & \\
\hline 1993-2018 & $-0.42 \pm 0.14$ & \\
\hline 1975-2000 & $-0.05 \pm 0.11^{*}$ & $-0.13 \pm 0.14$ (Maurer et al., 2019) \\
\hline 2001-2016 & $-0.32 \pm 0.12$ & $-0.48 \pm 0.15$ (Maurer et al., 2019) \\
\hline 2000-2012 & $-0.40 \pm 0.19$ & $-0.52 \pm 0.32$ (Vijay and Braun, 2016) \\
\hline $2000-2015$ & $-0.41 \pm 0.16$ & $-0.30 \pm 0.10$ (Mukherjee et al., 2018) \\
\hline \multirow[t]{2}{*}{ 2000-2016 } & $-0.41 \pm 0.16$ & $-0.37 \pm 0.09$ (Brun et al., 2017) \\
\hline & & $-0.31 \pm 0.08$ (Shean et al., 2020) \\
\hline \multirow[t]{2}{*}{ 1999-2011 } & $-0.49 \pm 0.20$ & $-0.45 \pm 0.13$ (Gardelle et al., 2012) \\
\hline & & $-0.44 \pm 0.09$ (Vincent et al., 2013) \\
\hline \multicolumn{3}{|c|}{ Upper Dudhkoshi catchment } \\
\hline 1980-2018 & $-0.37 \pm 0.04$ & \\
\hline 1980-1992 & $-0.19 \pm 0.07$ & \\
\hline 1993-2018 & $-0.46 \pm 0.05$ & \\
\hline 1975-2000 & $-0.29 \pm 0.06^{*}$ & $-0.29 \pm 0.05$ (Maurer et al., 2019) \\
\hline 1970-2007 & $-0.31 \pm 0.05^{*}$ & $-0.31 \pm 0.08$ (Bolch et al., 2011) \\
\hline 2001-2016 & $-0.44 \pm 0.05$ & $-0.39 \pm 0.06$ (Maurer et al., 2019) \\
\hline \multirow[t]{3}{*}{ 2000-2016 } & $-0.44 \pm 0.05$ & $-0.33 \pm 0.32$ (Brun et al., 2017) \\
\hline & & $-0.52 \pm 0.22$ (King et al., 2017) \\
\hline & & $-0.43 \pm 0.25$ (Shean et al., 2020) \\
\hline 1999-2011 & $-0.41 \pm 0.06$ & $-0.26 \pm 0.13$ (Gardelle et al., 2012) \\
\hline 1992-2008 & $-0.43 \pm 0.06$ & $-0.42 \pm 0.30$ (Nuimura et al., 2012) \\
\hline
\end{tabular}


Table S4. A comparison between the estimated glacier ice melt contribution to annual runoff from this study and that of from the available literature.

\begin{tabular}{llll}
\hline Study area & $\begin{array}{l}\text { Glacerised } \\
\text { fraction }\end{array}$ & Reference & $\begin{array}{l}\text { \% of glacier ice melt contribu- } \\
\text { tion to annual runoff }\end{array}$ \\
\hline Chandra catchment & 0.25 & This study & $31 \pm 11$ \\
Sutri Dhakha glacier & 0.50 & Singh et al. (2019) & $65 \pm 14$ \\
Chhota Shigri glacier & 0.50 & Azam et al. (2019) & $18 \pm 3$ \\
& & Engelhardt et al. (2017) & $33 \pm 4$ \\
\hline Upper Dudhkoshi catchment & 0.20 & This study & $32 \pm 9$ \\
Dudhkoshi catchment & 0.13 & Nepal (2016) & 5 \\
& & Andermann et al. (2012) & 4 \\
& & Racoviteanu et al. (2013) & 7 \\
& & Savèan et al. (2015) & 29 \\
Periche catchment & 0.43 & Mimeau et al. (2018) & 45 \\
\hline
\end{tabular}


Table S5. A comparison of glacier mass balance sensitivities to temperature and precipitation from this study with those available in the literature.

\begin{tabular}{|c|c|c|c|}
\hline & \multirow[t]{2}{*}{ References } & \multicolumn{2}{|c|}{ Glacier mass balance sensitivity to } \\
\hline & & Temperature $\left(\mathrm{mm} \mathrm{yr}^{-1}{ }^{\circ} \mathrm{C}\right)$ & $\begin{array}{l}\text { Precipitation }\left(\mathrm{mm}^{-1} \mathrm{r}^{-1} \text {, rela- }\right. \\
\text { tive to } 10 \% \text { change in precipi- } \\
\text { tation) }\end{array}$ \\
\hline \multicolumn{4}{|c|}{ Regional values } \\
\hline Chandra catchment & This study & $-475 \pm 93$ & $200 \pm 42$ \\
\hline $\begin{array}{l}\text { Upper Dudhkoshi } \\
\text { catchment }\end{array}$ & This study & $-274 \pm 46$ & $49 \pm 20$ \\
\hline $\begin{array}{l}\text { High mountain Asia } \\
\text { (HMA) }\end{array}$ & Wang et al. (2019) & -200 to -1490 & -20 to 160 \\
\hline Indus basin & Shea and Immerzeel (2016) & $-300 \pm 100$ to $-800 \pm 300$ & - \\
\hline Ganga basin & Shea and Immerzeel (2016) & $-300 \pm 200$ to $-800 \pm 400$ & - \\
\hline \multicolumn{4}{|c|}{ Glacier specific values } \\
\hline Chhota Shigri glacier & Azam et al. (2014) & -520 & 160 \\
\hline Zhadang glacier & Mölg et al. (2012) & -470 & 140 \\
\hline Dokriani glacier & Azam and Srivastava (2020) & -1110 & 240 \\
\hline
\end{tabular}


Table S6. A comparison of catchment wide runoff sensitivities to temperature and precipitation from this study, with those reported in the available literature.

\begin{tabular}{llll}
\hline References & Study area & $s_{T}\left(\mathrm{~mm} \mathrm{yr}^{-1}{ }^{\circ} \mathrm{C}\right)$ & $s_{P}\left(\mathrm{~mm} \mathrm{yr}^{-1} \mathrm{~mm}^{-1}\right)$ \\
\hline this study & Chandra catchment & $117 \pm 8$ & $0.39 \pm 0.03$ \\
& Upper Dudhkoshi catchment & $116 \pm 34$ & $0.47 \pm 0.06$ \\
Azam and Srivastava (2020) & Dokriani catchment & 620 & 0.98 \\
Pokhrel et al. (2014) & Dudhkoshi basin & $5.7 \pm 0.3$ & $0.6 \pm 0.02$ \\
\hline
\end{tabular}



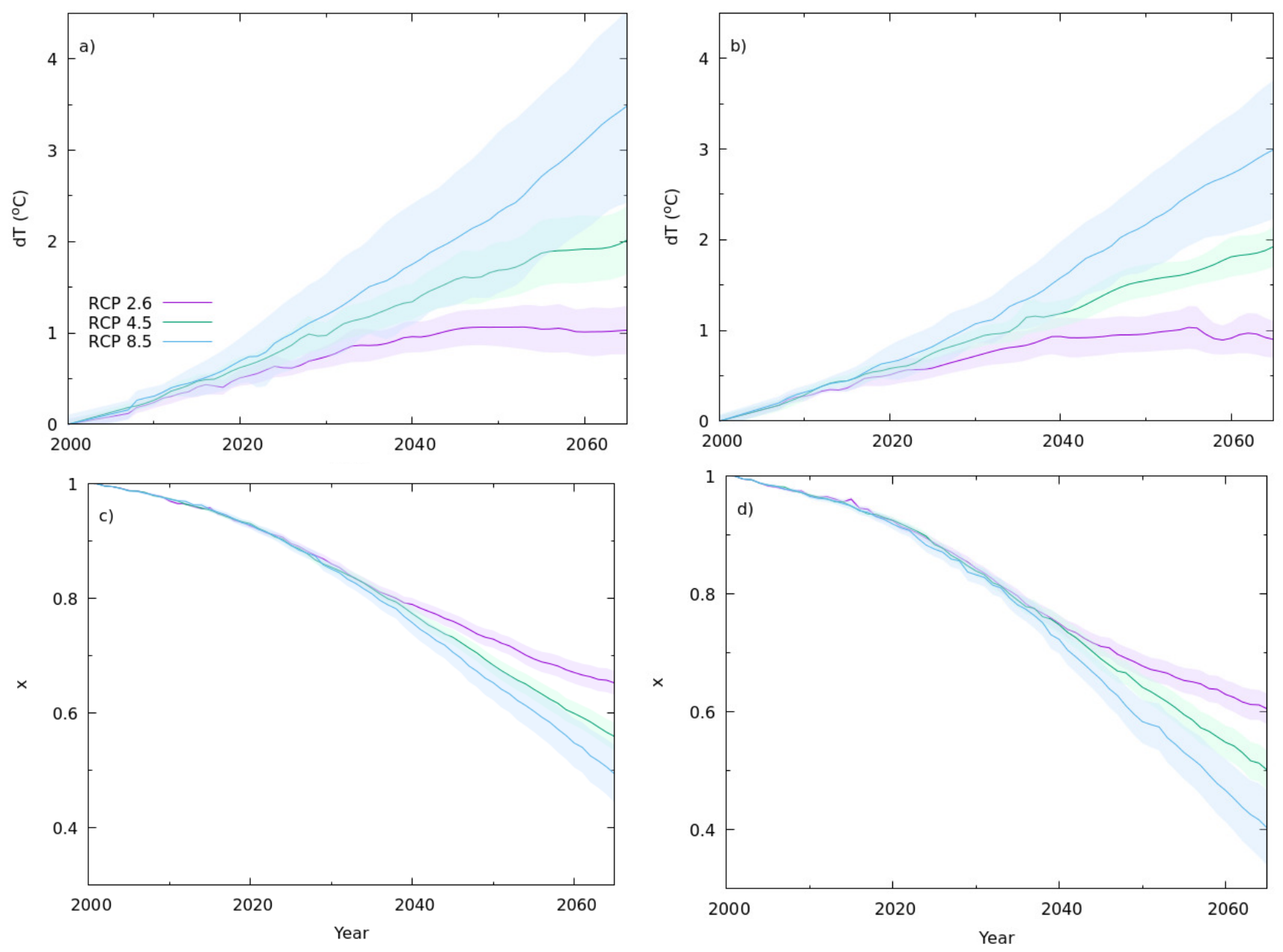

Figure S6. Projected temperature changes over the (a) western, and (b) eastern Himalaya predicted for three different climate scenarios (Kraaijenbrink et al., 2017). Kraaijenbrink et al. (2017) provided temperature change data from 2005 onward. Here we extrapolated the data between 2000-2005 using the trend between 2005-2010. Fractional changes in glacier area for (a) Indus, and (b) Ganga basins predicted using three RCP scenarios (Huss and Hock, 2018). In all the four plots, the band is showing the corresponding uncertainties associated with the future projection. 
Table S7. A comparison of the 'peak water' timing of the specific glacier runoff and the corresponding runoff increase for three climate scenarios from this study with the existing values.

\begin{tabular}{|c|c|c|c|c|}
\hline Climate scenario & $\begin{array}{l}\text { Year of peak water } \\
\text { (this study) }\end{array}$ & $\begin{array}{l}\% \text { runoff increase till } \\
\text { peak water } \\
\text { (this study) }\end{array}$ & $\begin{array}{l}\text { Year of peak water } \\
\text { (Huss and Hock, 2018) }\end{array}$ & $\begin{array}{l}\% \text { runoff increase till } \\
\text { peak water } \\
\text { (Huss and Hock, 2018) }\end{array}$ \\
\hline \multicolumn{5}{|c|}{ Chandra catchment } \\
\hline RCP 2.6 & $2033 \pm 7$ & $12 \pm 8$ & 2028 & 15 \\
\hline $\mathrm{RCP} 4.5$ & $2045 \pm 9$ & $20 \pm 10$ & 2033 & 23 \\
\hline RCP 8.5 & $2055 \pm 11$ & $28 \pm 13$ & 2040 & 30 \\
\hline \multicolumn{5}{|c|}{ Upper Dudhkoshi catchment } \\
\hline RCP 2.6 & $2022 \pm 5$ & $10 \pm 7$ & 2044 & 34 \\
\hline $\mathrm{RCP} 4.5$ & $2031 \pm 6$ & $13 \pm 9$ & 2058 & 47 \\
\hline RCP 8.5 & $2034 \pm 9$ & $17 \pm 12$ & 2067 & 57 \\
\hline
\end{tabular}




\section{References}

Andermann, C., Longuevergne, L., Bonnet, S., Crave, A., Davy, P., and Gloaguen, R. (2012). Impact of transient groundwater storage on the discharge of himalayan rivers. Nature Geoscience, 5 (2), 127-132. DOI: https://doi.org/10.1038/ngeo1356

Azam, M. F., Wagnon, P., Vincent, C., Ramanathan, A., Linda, A., Singh, V. B. (2014). Reconstruction of the annual mass balance of Chhota Shigri glacier, Western Himalaya, India, since 1969. Annals of Glaciology, 55(66), 69-80. DOI: https://doi.org/10.3189/2014AoG66A104

Azam, M. F., Wagnon, P., Vincent, C., Ramanathan, A. L., Kumar, N., Srivastava, S., ... Chevallier, P. (2019). Snow and ice melt contributions in a highly glacierized catchment of Chhota Shigri Glacier (India) over the last five decades. Journal of Hydrology, 574, 760-773. DOI: https://doi.org/10.1016/j.jhydrol.2019.04.075

Azam, M. F., and Srivastava, S. (2020). Mass balance and runoff modelling of partially debris-covered Dokriani Glacier in monsoondominated Himalaya using ERA5 data since 1979. Journal of Hydrology, 125432. DOI: https://doi.org/10.1016/j.jhydrol.2020.125432

Bolch, T., Pieczonka, T., and Benn, D. I. (2011). Multi-decadal mass loss of glaciers in the Everest area (Nepal Himalaya) derived from stereo imagery. The Cryosphere, 5(2), 349-358. DOI: https://doi.org/10.5194/tc-5-349-2011

Brun, F., Berthier, E., Wagnon, P., Kaab, A., Treichler, D. (2017). A spatially resolved estimate of High Mountain Asia glacier mass balances from 2000 to 2016. Nature geoscience, 10(9), 668-673. DOI: https://doi.org/10.1038/ngeo2999

15 Chevallier, Pierre, François Delclaux, Patrick Wagnon, Luc Neppel, Yves Arnaud, Michel Esteves, Devesh Koirala, Yves Lejeune, Frédéric Hernandez, Rémi Muller, Jean-Philippe Chazarin, Jean-François Boyer, Isabelle Sacareau. 2017. Paprika - Preshine hydrology data sets in the Everest Region (Nepal). 2010-18. Data base. 2017. DOI: https://doi.org/10.23708/000521.

Engelhardt, M., Ramanathan, A. L., Eidhammer, T., Kumar, P., Landgren, O., Mandal, A., and Rasmussen, R.(2017). Modelling 60 years of glacier mass balance and runoff for chhota shigri glacier, western himalaya, northern India. Journal of Glaciology, 63 (240), 618-628. DOI: https://doi.org/10.1017/jog.2017.29

Gardelle, J., Berthier, E., Arnaud, Y. (2012). Impact of resolution and radar penetration on glacier elevation changes computed from DEM differencing. Journal of Glaciology, 58(208), 419-422. DOI: https://doi.org/10.3189/2012JoG11J175

Hannah, D. M., and Gurnell, A. M. (2001). A conceptual, linear reservoir runoff model to investigate melt season changes in cirque glacier hydrology. Journal of hydrology, 246(1-4), 123-141. DOI: https://doi.org/10.1016/S0022-1694(01)00364-X

Huss, M., Hock, R. (2018). Global-scale hydrological response to future glacier mass loss. Nature Climate Change, 8(2), 135-140. DOI: https://doi.org/10.1038/s41558-017-0049-x

King, O., Quincey, D. J., Carrivick, J. L., and Rowan, A. V.: Spatial variability in mass loss of glaciers in the Everest region, central Himalayas, between 2000 and 2015, The Cryosphere, 11, 407-426. DOI: https://doi.org/10.5194/tc-11-407-2017, 2017.

Kraaijenbrink, P. D. A., Bierkens, M. F. P., Lutz, A. F., Immerzeel, W. W. (2017). Impact of a global temperature rise of 1.5 degrees Celsius on Asias glaciers. Nature, 549(7671), 257-260. DOI: https://doi.org/10.1038/nature23878

Lohmann, D., Raschke, E., Nijssen, B., Lettenmaier, D. P. (1998). Regional scale hydrology: I. Formulation of the VIC-2L model coupled to a routing model. Hydrological sciences journal, 43(1), 131-141. DOI: https://doi.org/10.1080/02626669809492107

Maurer, J. M., Schaefer, J. M., Rupper, S., Corley, A. (2019). Acceleration of ice loss across the Himalayas over the past 40 years. Science advances, 5(6), eaav7266. DOI: 10.1126/sciadv.aav7266

Mimeau, L., Esteves, M., Zin, I., Jacobi, H.-W., Brun, F., Wagnon, P., Koirala, D., and Arnaud, Y.: Quantification of different flow components in a high-altitude glacierized catchment (Dudh Koshi, Himalaya): some cryospheric-related issues, Hydrol. Earth Syst. Sci., 23, 3969-3996. DOI: https://doi.org/10.5194/hess-23-3969-2019, 2019. 
Mölg, T., Maussion, F., Yang, W., Scherer, D. (2012). The footprint of Asian monsoon dynamics in the mass and energy balance of a Tibetan glacier. The Cryosphere, 6(6), 1445. DOI: https://doi.org/10.5194/tc-6-1445-2012

40 Mukherjee, K., Bhattacharya, A., Pieczonka, T., Ghosh, S., Bolch, T. (2018). Glacier mass budget and climate reanalysis data indicate a climatic shift around 2000 in Lahaul-Spiti, western Himalaya. Climatic change, 148(1), 219-233. DOI: https://doi.org/10.1007/s10584018-2185-3

Nepal, S. (2016). Impacts of climate change on the hydrological regime of the Koshi river basin in the Himalayan region. Journal of HydroEnvironment Research, 10, 76-89. DOI: https://doi.org/10.1016/j.jher.2015.12.001

45 Nuimura, T., Fujita, K., Yamaguchi, S., Sharma, R. R. (2012). Elevation changes of glaciers revealed by multitemporal digital elevation models calibrated by GPS survey in the Khumbu region, Nepal Himalaya, 1992-2008. Journal of Glaciology, 58(210), 648-656. DOI: https://doi.org/10.3189/2012JoG11J061

Pratap, B., Sharma, P., Patel, L., Singh, A. T., Gaddam, V. K., Oulkar, S., Thamban, M. (2019). Reconciling High Glacier Surface Melting in Summer with Air Temperature in the Semi-Arid Zone of Western Himalaya. Water, 11(8), 1561. DOI: https://doi.org/10.3390/w11081561

Pokhrel, B. K., Chevallier, P., Andreassian, V., Tahir, A. A., Arnaud, Y., Neppel, L., ... Budhathoki, K. P. (2014). Comparison of two snowmelt modelling approaches in the Dudh Koshi basin (eastern Himalayas, Nepal). Hydrological sciences journal, 59(8), 1507-1518. DOI: https://doi.org/10.1080/02626667.2013.842282

Racoviteanu, A. E., Armstrong, R., and Williams, M. W. (2013). Evaluation of an ice ablation model to estimate the contribution of melting glacier ice to annual discharge in the nepal himalaya. Water Resources Research, 49 (9), 5117-5133. DOI: 10.1002/wrcr.20370

55 Shea, J. M., and Immerzeel, W. W. (2016). An assessment of basin-scale glaciological and hydrological sensitivities in the Hindu Kush-Himalaya. Annals of Glaciology, 57(71), 308-318. DOI: https://doi.org/10.3189/2016AoG71A073

Savéan, M., Delclaux, F., Chevallier, P., Wagnon, P., Gonga-Saholiariliva, N., Sharma, R., . . . Arnaud, Y. (2015). Water budget on the dudh koshi river (nepal): uncertainties on precipitation. Journal of Hydrology, 531, 850-862. DOI: https://doi.org/10.1016/j.jhydrol.2015.10.040

60 Shean, D. E., Bhushan, S., Montesano, P., Rounce, D. R., Arendt, A., Osmanoglu, B. (2020). A systematic, regional assessment of high mountain Asia glacier mass balance. Frontiers in Earth Science, 7, 363. DOI: https://doi.org/10.3389/feart.2019.00363

Sherpa, S. F., Wagnon, P., Brun, F., Berthier, E., Vincent, C., Lejeune, Y., ... Sinisalo, A. (2017). Contrasted surface mass balances of debrisfree glaciers observed between the southern and the inner parts of the Everest region (2007-15). Journal of Glaciology, 63(240), 637-651. DOI: https://doi.org/10.1017/jog.2017.30

65 Singh, A. T., Rahaman, W., Sharma, P., Laluraj, C., Patel, L. K., Pratap, B., . . Thamban, M. (2019). Moisture sources for precipitation and hydrograph components of the sutri dhaka glacier basin, western himalayas. Water, 11 (11), 2242. DOI: https://doi.org/10.3390/w11112242 Singh, A. T., Sharma, P., Sharma, C., Laluraj, C. M., Patel, L., Pratap, B., ... Thamban, M. (2020). Water discharge and suspended sediment dynamics in the Chandra River, Western Himalaya. Journal of Earth System Science, 129(1), 1-15. DOI: https://doi.org/10.1007/s12040020-01455-4

Vijay, S., and Braun, M. (2016). Elevation change rates of glaciers in the Lahaul-Spiti (Western Himalaya, India) during 2000-2012 and 2012-2013. Remote Sensing, 8(12), 1038. DOI: https://doi.org/10.3390/rs8121038

Vincent, C., Ramanathan, Al., Wagnon, P., Dobhal, D. P., Linda, A., Berthier, E., Sharma, P., Arnaud, Y., Azam, M. F., Jose, P. G., and Gardelle, J.: Balanced conditions or slight mass gain of glaciers in the Lahaul and Spiti region (northern India, Himalaya) during the nineties preceded recent mass loss, The Cryosphere, 7, 569-582. DOI: https://doi.org/10.5194/tc-7-569-2013, 2013. 
75 Wang, R., Liu, S., Shangguan, D., Radic, V., Zhang, Y. (2019). Spatial heterogeneity in glacier mass-balance sensitivity across High Mountain Asia. Water, 11(4), 776. DOI: https://doi.org/10.3390/w11040776 